\title{
Wnt Signaling in Bone Development and Disease: Making Stronger Bone with Wnts
}

\author{
Jean B. Regard ${ }^{1}$, Zhendong Zhong ${ }^{2}$, Bart O. Williams ${ }^{2}$, and Yingzi Yang ${ }^{1}$ \\ ${ }^{1}$ National Human Genome Research Institute, National Institutes of Health, Bethesda, Maryland 20892 \\ ${ }^{2}$ Center for Skeletal Disease Research, Van Andel Research Institute, Grand Rapids, Michigan 49503 \\ Correspondence: yingzi@mail.nih.gov
}

The skeleton as an organ is widely distributed throughout the entire vertebrate body. Wnt signaling has emerged to play major roles in almost all aspects of skeletal development and homeostasis. Because abnormal Wnt signaling causes various human skeletal diseases, Wnt signaling has become a focal point of intensive studies in skeletal development and disease. As a result, promising effective therapeutic agents for bone diseases are being developed by targeting the Wnt signaling pathway. Understanding the functional mechanisms of Wnt signaling in skeletal biology and diseases highlights how basic and clinical studies can stimulate each other to push a quick and productive advancement of the entire field. Here we review the current understanding of Wnt signaling in critical aspects of skeletal biology such as bone development, remodeling, mechanotransduction, and fracture healing. We took special efforts to place fundamentally important discoveries in the context of human skeletal diseases.

$T_{\mathrm{h}}^{\mathrm{h}}$ he skeleton has many important functions related to human health. Aside from the classical functions of the skeleton in structural support and movement, the bone matrix forms a major reservoir of calcium and other inorganic ions, and bone cells are active regulators of calcium homeostasis. Recent data suggest that bone cells can secrete hormones (e.g., FGF23 and osteocalcin) and likely play a physiologically significant role in regulating phosphate and energy homeostasis. It has emerged that Wnt signaling plays a major role controlling multiple aspects of skeletal development and maintenance. Thus, understanding how the Wnt pathway controls skeletal growth and homeostasis has broad implications for human health and disease.
Cartilage and bone define the skeleton and are produced by chondrocytes and osteoblasts, respectively. During embryonic development, bones are formed by two distinct processes: intramembranous and endochondral ossification (Fig. 1A). A number of cranial bones and the lateral portion of the clavicles are formed by intramembranous ossification. In this process, mesenchymal progenitor cells condense and differentiate directly into bone-forming osteoblasts. The majority of bones in our body are formed by endochondral ossification, during which mesenchymal progenitor cells condense and differentiate first into cartilage-forming chondrocytes to generate an avascular template of the future bone. Chondrocytes in these

Editors: Roel Nusse, Xi He, and Renee van Amerongen

Additional Perspectives on Wnt Signaling available at www.cshperspectives.org

Copyright (C) 2012 Cold Spring Harbor Laboratory Press; all rights reserved; doi: 10.1101/cshperspect.a007997

Cite this article as Cold Spring Harb Perspect Biol 2012;4:a007997 
J.B. Regard et al.

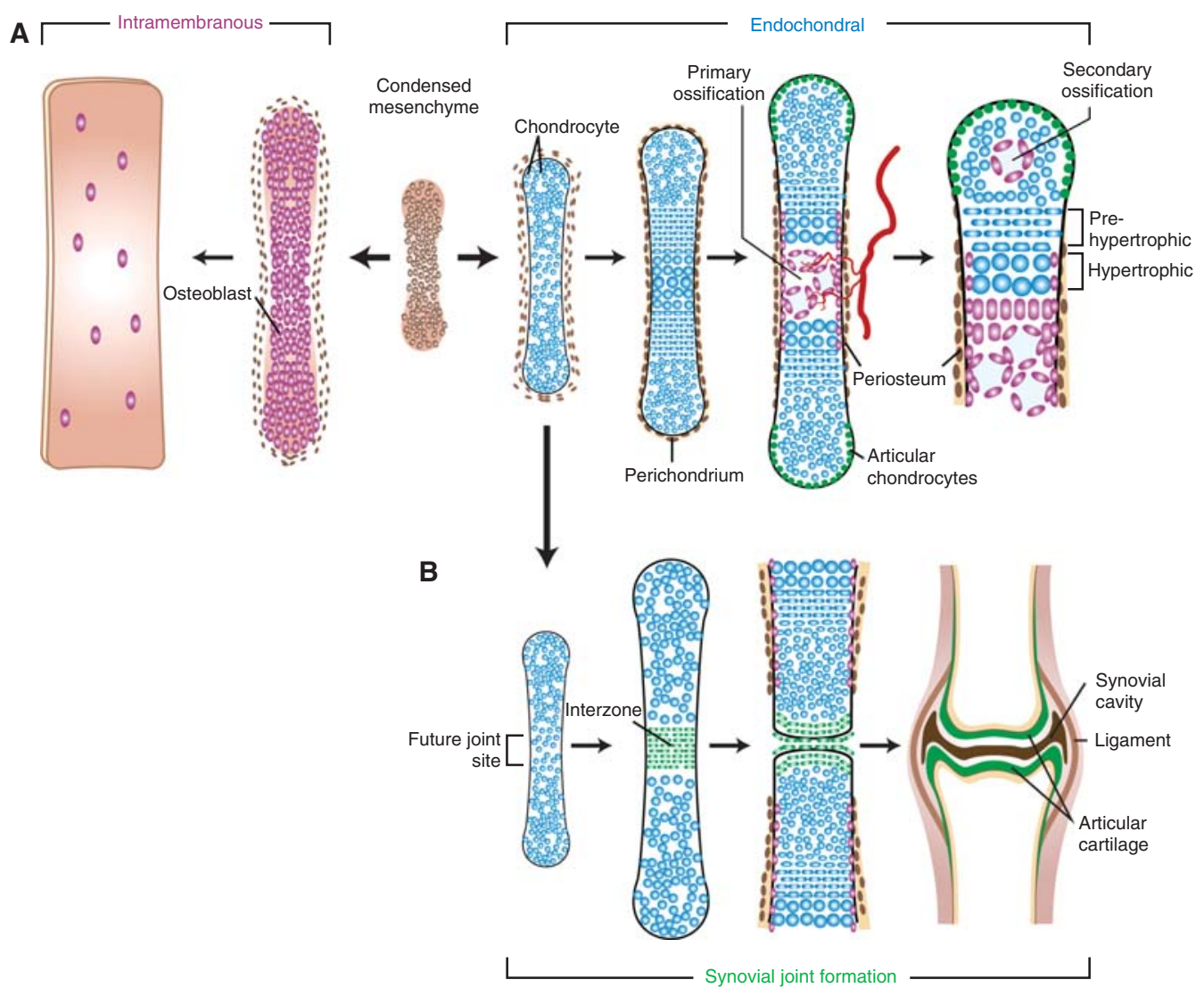

Figure 1. Mechanisms of skeleton formation. (A) Bones can form by either intramembranous or endochondral ossification. Both processes are initiated by the condensation of mesenchymal cells. During intramembranous ossification, mesenchymal cells differentiate directly into osteoblasts and deposit bone. During endochondral ossification, mesenchymal cells differentiate into chondrocytes and first make a cartilage intermediate. Chondrocytes in the center of the bone initiate a growth plate, stop proliferating, and undergo hypertrophy. Hypertrophic chondrocytes mineralize their matrix and undergo apoptosis, attracting blood vessels and osteoblasts that remodel the intermediate into bone. $(B)$ The first histologic sign of synovial joint formation is the gathering and flattening of cells, forming the interzone. Cavitation occurs within the presumptive joint separating the two cartilaginous structures. Remodeling and maturation proceed to give rise to the mature synovial joint. Wnt signaling plays a significant role in controlling almost all aspects of skeleton formation. Osteoblasts (purple); chondrocytes (blue); osteochondroprogenitor cells (brown).

templates undergo a program of proliferation and progressive cellular maturation. Eventually, they exit the cell cycle and become pre-hypertrophic, then terminally differentiating into hypertrophic chondrocytes, which are eliminated ultimately by apoptosis. Hypertrophic chondrocytes produce a matrix that is calcified and functions as a scaffold for new bone formation. Concomitant with chondrocyte hypertrophy, osteoclasts, osteoblasts, and blood vessels mi- grate in from perichondral regions and remodel this template into bone.

The developing skeletal elements are often segmented to form joints, which are required to support mobility. Synovial joints, which allow movement via smooth articulation between bones, form when chondrogenic cells in a newly formed cartilage undergo a program of dedifferentiation and flattening to form an interzone (Fig. 1B). Cavitation occurs within the flattened 
cells, allowing physical separation of the skeletal elements, and the formation of the synovial cavity. Cells and tissues in and around the interzone are remodeled at the same time to form the articular cartilage and other joint structures. Failure to form or maintain joints leads to joint fusion or osteoarthritis, a major skeletal disease.

Following its formation, bone remains a regenerative tissue and is maintained during postnatal life by continuous remodeling. This highly active, homeostatic process is required for its functions and is controlled by three cell types: osteoblasts on the bone surface that deposit new bone matrix; osteocytes embedded in bone that are terminally differentiated from osteoblasts and function as mechanical and metabolic sensors; and the matrix-resorbing osteoclasts (Fig. 2). Osteoblasts are derived from mesenchymal stem cells (MSCs), whereas osteoclasts differentiate from hematopoietic progenitors. Decreased bone mass may be due to reduced osteoblast function or elevated osteoclast activity, and, conversely, increased bone mass may result from increased osteoblast function or decreased osteoclast activity. The precise balance of formation and resorption is critical for maintain-
Wnt Signaling in Bone Development and Disease

ing normal bone mass, and alterations in this balance lead to common bone diseases such as osteoporosis and osteopetrosis.

There are two major bone types, cortical and trabecular, which show different anatomical properties (Fig. 2). Cortical (or compact) bone is the solid, densely packed bone that forms the outer layer of most bones and gives strength and rigidity. Trabecular (or cancellous) bone is present mostly in the marrow cavities of long bones and is the dominant bone type in vertebral bodies. Trabecular bone forms a porous, cobweb-like network of trabeculae whose large surface area is thought to facilitate the metabolic activity of bones mediated by osteoblasts and osteoclasts. Trabeculae are sites of active remodeling and will often orient in the direction of mechanical loading, dissipating the energy of loading and adding to bone strength. It is trabecular bone, rather than cortical bone, which is most severely affected in osteoporosis.

The Wnt/ $\beta$-catenin pathway plays a major role in controlling skeletal development and homeostasis, which are the focus of this work. We focus not only on differentiation of skeletal cells and formation of skeletal tissues, but also on the

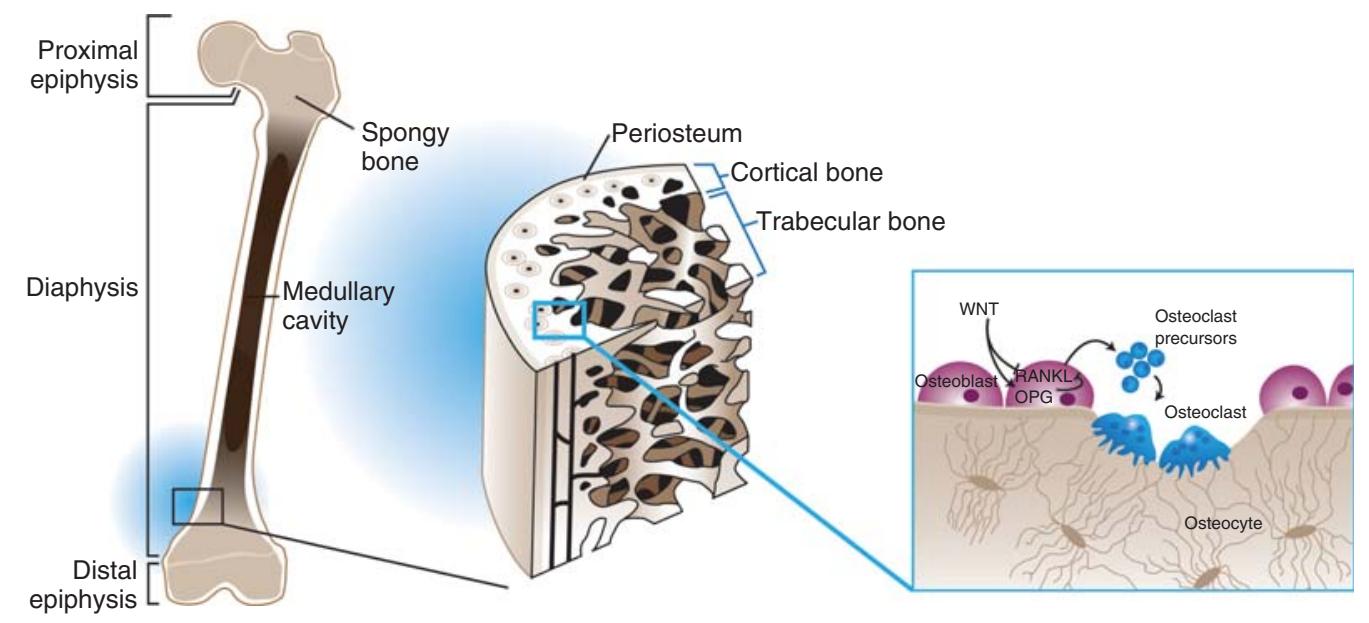

Figure 2. Anatomy of bone. Cortical and trabecular bone represent the two major forms of bone. Osteoblasts (dark purple) are present on the surface and form new bone. Osteocytes (brown) are terminally differentiated osteoblasts that have become embedded in bone and communicate information to one another and to cells on the surface to regulate bone homeostasis. Osteoclasts (blue) are of hematopoietic origin and catabolize bone. A major function of Wnt $/ \beta$-catenin signaling in osteoblasts is to suppress RANKL and to promote OPG production, thereby inhibiting osteoclast formation. 
J.B. Regard et al.

role of the $\mathrm{Wnt} / \beta$-catenin signaling pathway on bone homeostasis, mechanotransduction, and wound healing, paying particular attention to human and mouse studies.

\section{WNT/ $\beta$-CATENIN SIGNALING IN HUMAN SKELETAL DISEASES}

The importance of the Wnt/ $\beta$-catenin signaling pathway in patterning, development, and maintenance of the human skeleton is underscored by the number of human bone diseases associated with mutations in this pathway (Table 1). Early in skeletal development, Wnt signaling controls pattern formation before skeletal elements are laid down, and abnormal Wnt signaling is associated with defects of the human skeleton. At the more extreme end of the spectrum, loss of WNT3 leads to tetra-amelia, a severe congenital defect in which all four limbs fail to form, as well as craniofacial defects (Niemann et al. 2004). At the milder end of the spectrum, mutations in the $\mathrm{Wnt} / \beta$-catenin pathway inhibitor AXIN2 leads to a dominant, familial form of tooth agenesis, in which a large number of permanent teeth fail to form (Table 1) (Lammi et al. 2004).

The first human genetic evidence revealing the importance of the Wnt/ $\beta$-catenin pathway in bone formation came from the work of Gong et al. (2001) that identified several loss-of-function (LOF) mutations in the low-density lipoprotein receptor-related protein 5 (LRP5) associated with autosomal recessive osteoporosis pseudoglioma (OPPG) syndrome. Patients suffer from a dramatic reduction in trabecular bone leading to multiple fractures and bone deformities. LRP5 loss-of-function mutations have subsequently been shown to be associated with juvenile osteoporosis (Saarinen et al. 2007). Conversely, gain-of-function mutations of LRP5 lead to the opposite phenotype: autosomaldominant high bone mass and enhanced bone strength (Boyden et al. 2002; Little et al. 2002; Van Wesenbeeck et al. 2003). Loss-of-function mutations in the closely related LRP6 lead to an autosomal-dominant familiar form of coronary artery disease associated with osteoporosis (Mani et al. 2007).
Mutations in the secreted Wnt/ $\beta$-catenin signaling antagonist sclerostin (SOST) cause two overlapping diseases: sclerosteosis and van Buchem disease (Balemans et al. 2001, 2002; Brunkow et al. 2001). Sclerosteosis is a rare autosomal-recessive skeletal dysplasia mostly affecting the Afrikaner population of South Africa. It is caused by loss-of-function mutations in the SOST gene and is marked by hand malformations, unrestrained bone growth leading to thickened and sclerotic bones, and high bone mass. Bone overgrowth is generalized but most severe in the cranium, leading to increased intracranial pressure and pinching of cranial nerves causing facial palsy and loss of hearing and smell. Interestingly, heterozygous carriers of these SOST mutations have increased bone mineral density, suggesting that one affected allele is sufficient to confer a skeletal phenotype and the effects are dominant (Gardner et al. 2005). Most patients with van Buchem disease come from a fishing village in the Netherlands and present with a similar, although milder, sclerosing bone dysplasia affecting mainly cranial bones. Unlike sclerosteosis, van Buchem disease is not caused by mutations in the SOST gene coding sequence, but rather by a deletion of an enhancer region downstream causing reduced expression of SOST.

Although it has long been recognized that bone mass and predisposition to osteoporosis are highly heritable, the mechanism and genes involved have been poorly defined. Several recent genomic screens (both genome-wide association studies as well as more targeted screens) have identified polymorphisms in or close to Wnt/ $\beta$-catenin signaling components that correlate with bone mineral density and further strengthen the importance of this pathway in human bone physiology. Polymorphisms in LRP5, LRP6, GPR177 (Wntless), SFRP1, SOST, and RSPO3 have all been reported to be associated with bone parameter variations in humans (Uitterlinden et al. 2004; van Meurs et al. 2006; Sims et al. 2008; Duncan et al. 2011). Studies using mouse genetics have revealed causative and fundamentally important roles of Wnt $/ \beta$ catenin signaling in skeletal biology and further established in vivo experimental models to 
Wnt Signaling in Bone Development and Disease

Table 1. Human and mouse genetic analysis of Wnt signaling in skeletal biology

\begin{tabular}{|c|c|c|c|}
\hline Human gene & Human disease & Skeletal phenotype & References \\
\hline LRP5 & $\begin{array}{l}\text { Osteoporosis-pseudoglioma } \\
\text { syndrome }\end{array}$ & Low bone mass & Gong et al. 2001 \\
\hline LRP5 & Juvenile osteoporosis & Low bone mass & $\begin{array}{l}\text { Gong et al. 2001; Saarinen } \\
\text { et al. } 2007\end{array}$ \\
\hline LRP5 & Osteopetrosis & High bone mass & $\begin{array}{l}\text { Boyden et al. 2002; Little et } \\
\text { al. 2002; Van } \\
\text { Wesenbeeck et al. } 2003\end{array}$ \\
\hline LRP6 & Osteoporosis & Low bone mass & Mani et al. 2007 \\
\hline SOST & $\begin{array}{l}\text { Sclerosteosis, Van Buchem } \\
\text { disease }\end{array}$ & $\begin{array}{l}\text { High bone mass, bone } \\
\text { overgrowth }\end{array}$ & $\begin{array}{l}\text { Balemans et al. 2001, 2002; } \\
\text { Brunkow et al. 2001 }\end{array}$ \\
\hline AXIN2 & Tooth agenesis & Fewer permanent teeth & Lammi et al. 2004 \\
\hline WNT3 & Tetra-amelia & Absence of all four limbs & Niemann et al. 2004 \\
\hline Mouse allele & \multicolumn{2}{|c|}{ Skeletal phenotype } & References \\
\hline
\end{tabular}

\section{$\boldsymbol{\beta}$-Catenin conditional LOF}

Dermol-cre Reduced osteoblastogenesis, ectopic chondrogenesis, survival to birth

Prx1-cre

Colla1(2.3)-cre

Reduced osteoblastogenesis, ectopic chondrogenesis, survival to birth

Osteocalcin-cre

Normal osteoblastogenesis, increased osteoclastogenesis and bone resorption, reduced bone mass, normal life span

DMP1-cre

Reduced osteoblastogenesis, increased osteoclastogenesis, reduced bone mass, survival to $5 \mathrm{wk}$

Normal osteoblastogenesis, increased osteoclastogenesis, reduced bone mass, survival to 3 mo

\section{$\boldsymbol{\beta}$-Catenin conditional GOF}

Prxl-cre Reduced differentiation of osteoblasts and chondrocytes

Col2-cre Reduced chondrocyte differentiation, impaired joint formation

Colla1(2.3)-cre High bone mass, reduced osteoclastogenesis

\section{APC conditional LOF}

Osteocalcin-cre High bone mass, increased osteoblastogenesis, reduced osteoclastogenesis, survival to $2 \mathrm{wk}$

LRP5 KO
Day et al. 2005; Hu et al. 2005

Hill et al. 2005

Glass et al. 2005

Holmen et al. 2005

Kramer et al. 2010

Hill et al. 2005

Guo et al. 2004

Glass et al. 2005

Holmen et al. 2005

Kato et al. 2002; Fujino et al. 2003; Holmen et al. 2004

LRP5 conditional LOF

Prx1-cre

Reduced bone mass in limbs, normal bone mass in spine

Villin-cre

Reduced bone mass

Villin-cre

Normal bone mass

Colla1(2.3)-cre

Normal bone mass

DMP1-cre

Reduced bone mass

LRP5 GOF

Increased bone mass, bone formation rate, bone strength

Villin-cre Increased bone mass

Villin-cre Normal bone mass
Cui et al. 2011

Yadav et al. 2008

Cui et al. 2011

Yadav et al. 2008

Cui et al. 2011

Babij et al. 2003; Yadav et al. 2008; Cui et al. 2011

Yadav et al. 2008

Cui et al. 2011

Continued 
J.B. Regard et al.

\begin{tabular}{|c|c|c|}
\hline Mouse allele & Skeletal phenotype & Reference \\
\hline DMP1-cre & Increased bone mass & Cui et al. 2011 \\
\hline LRP6 KO & $\begin{array}{l}\text { Interacts genetically with Lrp5 to reduce bone } \\
\text { mass }\end{array}$ & Holmen et al. 2004 \\
\hline $\begin{array}{l}\text { Ringelschwanz (Rs) (LRP6 LOF } \\
\text { hypomorph) }\end{array}$ & Delayed ossification, reduced bone mass & Kokubu et al. 2004 \\
\hline $\begin{array}{l}\text { Crooked tail (Cd) (LRP6 GOF } \\
\text { hypomorph) }\end{array}$ & Delayed ossification & Carter et al. 2005 \\
\hline Axin $2 \mathrm{KO}$ & $\begin{array}{l}\text { Increased osteoblastogenesis and maturation, } \\
\text { craniosynostosis }\end{array}$ & Yu et al. 2005 \\
\hline Dkk1 Het & Increased bone formation & Morvan et al. 2006 \\
\hline $\begin{array}{l}\text { Doubleridge (Dkk1 LOF } \\
\text { hypomorph) }\end{array}$ & Increased bone mass & $\begin{array}{l}\text { MacDonald et al. } \\
2007\end{array}$ \\
\hline Sfrp1 KO & $\begin{array}{l}\text { Increased trabecular bone mass, increased } \\
\text { osteoblastogenesis }\end{array}$ & Bodine et al. 2004 \\
\hline Sfrp3 KO & $\begin{array}{l}\text { Stiffer bone with increased cortical bone } \\
\text { thickness and density }\end{array}$ & Lories et al. 2007 \\
\hline Sost KO & Increased bone formation & Li et al. 2008 \\
\hline Gsk3 $\beta$ Het & Increased bone formation & $\begin{array}{l}\text { Kugimiya et al. } \\
\qquad 2007\end{array}$ \\
\hline Wnt10b KO & Reduced bone mass & Bennett et al. 2005 \\
\hline Fzd9 KO & Reduced bone formation & Albers et al. 2011 \\
\hline Naked cuticle 1 and $2 \mathrm{KO}$ & Craniofacial abnormalities & Zhang et al. 2007 \\
\hline Lef1 Het & $\begin{array}{l}\text { Reduced bone mass in females, decreased } \\
\text { osteoblast function }\end{array}$ & Noh et al. 2009 \\
\hline Tcf1 KO & Reduced bone mass, increased osteoclastogenesis & Glass et al. 2005 \\
\hline
\end{tabular}

investigate the pathological mechanisms of human mutations in Wnt pathway components during human bone formation and homeostasis (see below).

\section{WNT $/ \beta$-CATENIN SIGNALING IN OSTEOBLAST DIFFERENTIATION AND MATURATION}

The mouse has proven to be a productive animal model for the genetic dissection of $\mathrm{Wnt} / \beta$-catenin signaling in bone biology (Fig. 3), and work from a number of groups has shown that Wnt/ $\beta$-catenin signaling regulates multiple aspects of skeletal development, controlling the differentiation and function of MSCs, chondrocytes, osteoblasts, and osteoclasts. During skeletogenesis, conditional removal of $\beta$-catenin in mesenchymal progenitor cells leads to decreased osteoblast differentiation (Day et al. 2005; Hill et al. 2005; Hu et al. 2005; Rodda and McMahon 2006). Cells surrounding the developing bones are capable of expressing early markers of the osteoblast lineage (i.e., Runx2), but fail to express Osterix, a marker of osteoblast commitment. Indeed, removal of $\beta$-catenin in osteoblast progenitor cells promoted chondrogenesis in vitro and ectopic chondrocyte differentiation at the expense of osteoblasts in vivo (Day et al. 2005; Hill et al. 2005). This suggests that, in vivo in an osteochondral progenitor cell, high Wnt/ $\beta$-catenin signaling promotes osteoblast differentiation and inhibits chondrogenesis. Indeed, ectopic activation of $\mathrm{Wnt} / \beta$-catenin signaling suppresses chondrogenic differentiation from mesenchymal progenitors in culture (Rudnicki and Brown 1997; Day et al. 2005; Reinhold et al. 2006). However, the effect of Wnt/ $\beta$-catenin signaling on osteoblast formation appears to 
Wnt Signaling in Bone Development and Disease

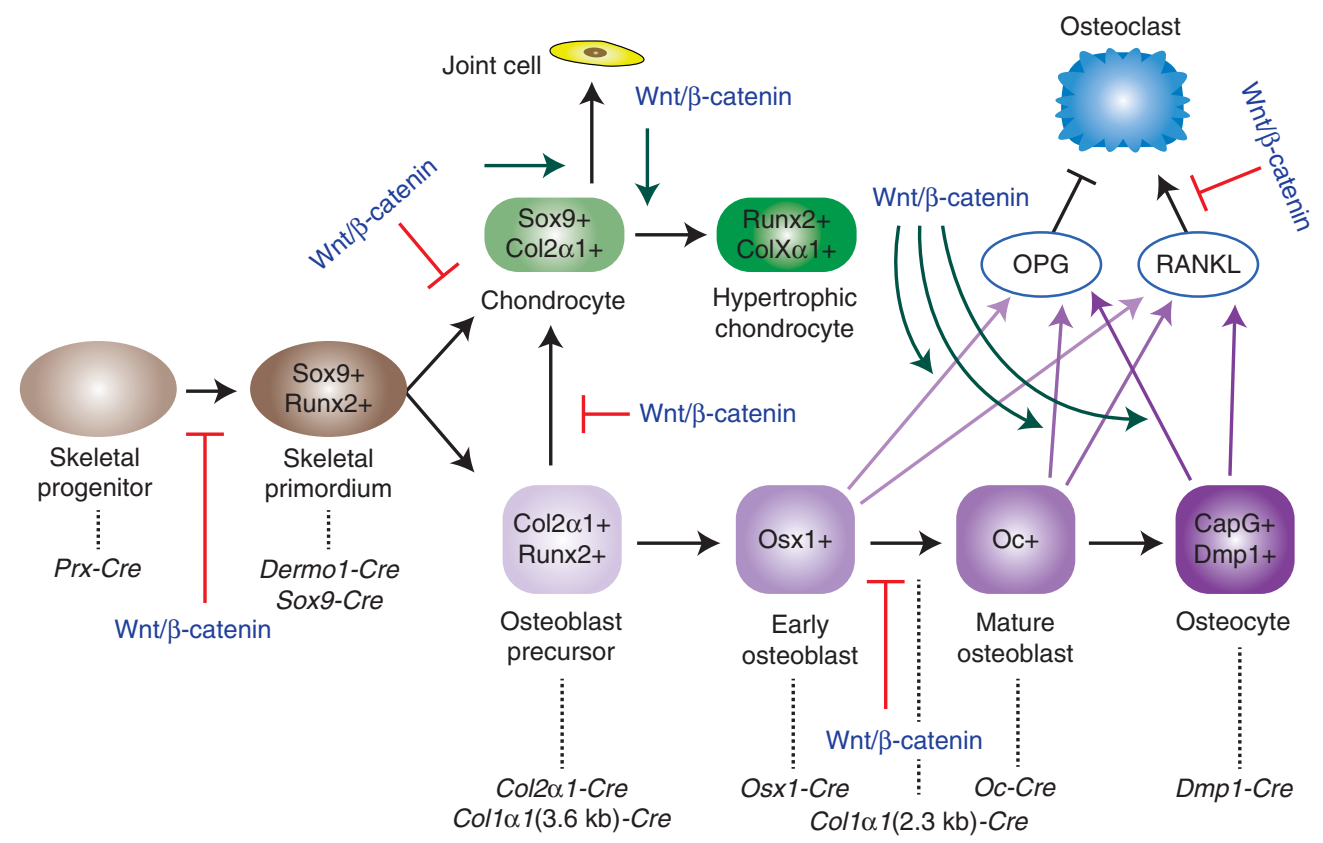

Figure 3. Genetic dissection of skeletal cells using mouse genetics. Schematic diagram of the differentiation of chondrocytes and osteoblasts from a common osteochondral progenitor cell. Overlaid are the corresponding mouse Cre-recombinase lines that allow for the in vivo dissection of signaling pathways. Regulation of cell differentiation by Wnt/ $\beta$-catenin signaling is indicated (green for activation and red for inhibition). (Figure created from data from Day et al. 2005, Hill et al. 2005, Hu et al. 2005, Rodda and McMahon 2006, Zylstra et al. 2008, and Bonewald 2011.)

depend on the developmental stage of the cells. In vitro activation of the $\mathrm{Wnt} / \beta$-catenin signaling pathway in MSCs promotes their proliferation and inhibits osteoblastic differentiation (Boland et al. 2004; de Boer et al. 2004; Cho et al. 2006; Regard et al. 2011). Once MSCs have been committed to the osteoblast lineage, Wnt/ $\beta$-catenin signaling promotes their growth and differentiation, but can also block their terminal differentiation into mature osteoblasts (Kahler and Westendorf 2003; Kahler et al. 2006, 2008; Rodda and McMahon 2006; Eijken et al. 2008). This stage-dependent function of Wnt $/ \beta$-catenin signaling in bone development is also manifested in human diseases. For instance, fibrous dysplasia (FD) caused by activated Gas protein is due to inhibition of osteoblast differentiation, and maturation resulted from up-regulated $\mathrm{Wnt} / \beta$-catenin signaling in MSCs and/or early osteoblasts (Regard et al. 2011).

\section{WNT/ $\beta$-CATENIN SIGNALING IN CARTILAGE AND SYNOVIAL JOINT FORMATION}

Removal of $\beta$-catenin from chondrocytes disrupts normal endochondral ossification and leads to neonatal lethality (Akiyama et al. 2004; Day et al. 2005). Mutant knockout mice displayed delayed formation of hypertrophic chondrocytes, reduced chondrocyte proliferation and survival, delays in blood vessel invasion, ossification, and cleft palates. Thus, $\beta$-catenin inhibits chondrogenesis, but, once cartilage has formed, it promotes maturation and survival of chondrocytes in the growth plate. Removal of the Wnt antagonist secreted Frizzled-related protein 1 (sFRP1) in mice led to a diminished growth plate and increased calcification in the hypertrophic zone, and accelerated differentiation of hypertrophic chondrocytes (Gaur et al. 2006). A similar phenotype is seen in Axin2-null mice 
J.B. Regard et al.

that were runted and showed evidence of accelerated chondrocyte maturation (Dao et al. 2010). Constitutive activation of $\beta$-catenin in chondrocytes and skeletal mesenchyme also caused neonatal lethality with severe chondrodysplasia (Akiyama et al. 2004; Guo et al. 2004; Hill et al. 2005). Activation led to small, hypoplastic skeletal elements with disorganized growth plates. It should be noted that although $\mathrm{Wnt} / \beta$-catenin signaling plays a major role in promoting chondrocyte differentiation, maturation, and survival (Mak et al. 2006), chondrocytes still mature eventually (despite a significant delay), and most chondrocytes do survive, suggesting there are other pathways in cartilage that can support chondrocyte hypertrophy and survival independently of $\mathrm{Wnt} / \beta$-catenin signaling.

Wnt signaling has also been shown to play an inductive role in synovial joint formation. Topgal, a transgenic LacZ readout of endogenous Wnt/ $\beta$-catenin signaling, marks sites of joint formation (Guo et al. 2004). Wnt4, Wnt9a (formerly known as Wnt14), and Wnt16 are expressed early in the development of interzones and can function as markers of synovial joint formation (Guo et al. 2004). However, inactivation of both Wnt4 and Wnt9a leads to only limited joint fusion (Spater et al. 2006), suggesting that removing more Wnt ligands (such as Wnt16) may be required to address the importance of Wnts in this process. $\beta$-Catenin is required for the development of synovial joints, because its removal before interzone formation led to a reduction in markers of synovial joint formation and resulted in joint fusions (Guo et al. 2004; Spater et al. 2006). Importantly, removal of $\beta$-catenin from the joint region following interzone formation led to a very mild joint phenotype, indicating that Wnt $/ \beta$-catenin signaling is particularly important early in joint induction (Fig. 3) (Koyama et al. 2008).

Different from the growth plate cartilage, articular cartilage coats the ends of long bones. Although growth plate cartilage matures and turns over quickly, articular cartilage undergoes minimal turnover and is essentially maintained as a permanent tissue. Pathways that control the maintenance of joints and articular cartilage are particularly important for the treatment of osteoarthritis (OA), which is characterized by inappropriate hypertrophy of articular chondrocytes and degradation of extracellular matrix leading to loss of articular cartilage. Much of the available data suggest that activation of Wnt $/ \beta$-catenin signaling leads to loss of a stable chondrocyte phenotype and destruction of cartilaginous tissues. Genome-wide analysis in human has shown an association between a functional single nucleotide polymorphism (SNP) in secreted Frizzled-related protein 3 (sFRP3, also called FRZB), a Wnt antagonist (Loughlin et al. 2004). Inactivation of sfrp3 in mice resulted in grossly normal cartilage development; however, mutant mice showed increased cartilage damage in models of OA (Lories et al. 2007). In addition, conditional activation of $\beta$-catenin postnatally in articular chondrocytes leads to an OA-like phenotype, suggesting that Wnt $\beta$ catenin signaling continues to be important in maintaining synovial joints (Zhu et al. 2009).

\section{WNT / $\beta$-CATENIN SIGNALING IN OSTEOBLAST FUNCTION}

$\mathrm{Wnt} / \beta$-catenin signaling remains important throughout life, playing a central role in controlling bone mass. In mature osteoblasts in vivo, the $\mathrm{Wnt} / \beta$-catenin signaling pathway continues to be important, and a major function appears to be in the control of osteoclast formation. Deletion of $\beta$-catenin in osteoblasts using the Cre recombinase driven by either the human Osteocalcin or Collagen $1 \alpha 1(2.3 \mathrm{~kb})$ promoters caused severe low bone mass with strikingly increased osteoclastogenesis, whereas constitutive activation of $\beta$-catenin under the same conditions resulted in dramatically increased bone deposition with reduced osteoclast formation (Glass et al. 2005; Holmen et al. 2005). Consistent with these, Wnt7b $\mathrm{b}^{-/-}$and $\mathrm{Wnt} 10 \mathrm{~b}^{-/-}$ mice have produced low bone mass phenotypes (Bennett et al. 2005; Tu et al. 2007). Because it is known that multiple Wnts and Fzds are expressed in the developing bone, it is likely that functional redundancy is masking the relative in vivo importance of these factors. It is likely that work with mice carrying conditional deletions 
in either the Porcupine or Wntless/GPR177/ Evi genes, which are both specifically required for secretion of Wnt ligands from Wnt-producing cells (Hausmann et al. 2007; Lorenowicz and Korswagen 2009), may help to address these questions (Fu et al. 2011; Stefater et al. 2011).

Bone formation has to be coupled to bone resorption in a delicate balance in order to maintain a healthy bone. This is achieved through an interaction between osteoblasts and osteoclasts. Osteoclast differentiation is regulated by at least three genes expressed in osteoblasts: macrophage colony-stimulating factor (M-CSF), receptor activator of nuclear factor $\mathrm{\kappa}-\mathrm{B}$ ligand (RANKL) and osteoprotegrin (Opg). RANKL is expressed on the surface of osteoblasts and stimulates osteoclast maturation through interactions with its receptor, RANK, which is expressed at the surface of osteoclast precursors. Opg is a secreted decoy receptor for RANKL that functions to inhibit osteoclastogenesis by disrupting RANKL-RANK interaction (Fig. 2). Both RANKL and Opg expression can be controlled by Wnt $/ \beta$-catenin signaling. Opg has been shown to be a direct target of $\beta$-catenin transcriptional activation, and loss of $\beta$-catenin leads to decreased Opg expression and increased osteoclast activity (Glass et al. 2005; Holmen et al. 2005). $\beta$-Catenin-deficient osteoblasts have also been documented to express higher RANKL expression (Holmen et al. 2005). Conversely, activation of Wnt/ $\beta$-catenin signaling by stabilizing $\beta$-catenin increased Opg expression and bone formation (Glass et al. 2005). In addition, activating the pathway by removing adenomatous polyposis coli (Apc) in osteoblasts showed reduced RANKL expression and elevated Opg levels (Holmen et al. 2005). Lef1 and Tcf1 are major downstream mediators of $\mathrm{Wnt} / \beta$-catenin signaling in osteoblasts, because their loss is associated with reduced bone mass and, in the case of Tcf1, increased osteoclastogenesis (Glass et al. 2005; Noh et al. 2009).

$\mathrm{Wnt} / \beta$-catenin signaling activity is tightly regulated by secreted antagonists, one of which is Dkk1, which also plays a critical role in bone formation. Dkk1 ${ }^{-/-}$mice die in utero because of lack of head formation and also show limb defects with altered cell proliferation and sur-
Wnt Signaling in Bone Development and Disease

vival (Mukhopadhyay et al. 2001). Dkk1 $1^{+/-}$ mice, however, survive and show higher numbers of osteoblasts and increased bone mass, demonstrating that partial loss of Dkk1 is sufficient to generate skeletal phenotypes (Morvan et al. 2006). Indeed, a Dkk1 allelic series including a hypomorphic Dkk1 allele (doubleridge; Dkk1 $^{\mathrm{d}}$ ) showed that bone mass correlates inversely with Dkk1 levels (MacDonald et al. 2007). Consistent with Dkk1 suppressing bone formation in vivo, transgenic mice expressing Dkk1 under control of osteoblast promoters are osteopenic (Li et al. 2006; Guo et al. 2010). In addition, a Dkk1-neutralizing antibody promotes bone formation when injected into mice (Yaccoby et al. 2007). Kremens, the Dkk1 coreceptors, also play physiologically significant roles in bone formation. Ablation of both kremens (Krm1 and Krm2) increased trabecular bone volume twofold and was associated with increased osteoblast number and function (Ellwanger et al. 2008). Krm2 is likely the more relevant gene in bone, because $\mathrm{Krm} 2^{-/-}$mice developed a high bone mass phenotype and overexpression of $\mathrm{Krm} 2$ in bone led to severe osteoporosis with decreased osteoblast and elevated osteoclast differentiation and function (Schulze et al. 2010).

Sost is another secreted Wnt antagonist that is specifically expressed in osteocytes, and its overexpression in bone results in decreased osteoblast numbers and reduced bone formation rate (Winkler et al. 2003). Sost ${ }^{-1-}$ mice show high bone mass in both cortical and trabeular bone compartments due to increased osteoblast numbers and normal osteoclast functions ( $\mathrm{Li}$ et al. 2008). Sost-neutralizing antibodies have also been shown to promote bone formation and increase bone mass in a rat model of osteoporosis (Li et al. 2009).

Secreted Frizzled-related proteins (Sfrps) bind Wnt ligands and are Wnt pathway antagonists proving to be important in bone formation. Although widely expressed during development, phenotypes of the Sfrp1 $1^{-/-}$mice appear to be largely restricted to skeletal tissues (Bodine et al. 2004; Morvan et al. 2006; Li et al. 2008). Sfrp1 ${ }^{-/-}$mice have normal cortical bone but increased trabecular bone associated with 
J.B. Regard et al.

decreased osteoblast apoptosis and enhanced osteoblast function. Although modest, Sfrp $3^{-/-}$ mice show increased cortical bone thickness and density and demonstrated increased stiffness relative to controls (Lories et al. 2007).

Axin2, an intracellular negative regulator of Wnt $/ \beta$-catenin signaling, also regulates bone formation. Loss of Axin 2 leads to enhanced proliferation and differentiation of osteoblasts, and Axin $2^{-/-}$mice develop craniosynostosis, a premature closure of cranial sutures (Yu et al. 2005). This phenotype can be rescued by reducing levels of $\beta$-catenin (Liu et al. 2007). Compound Axin $2^{-/-}$; Axin $1^{+/-}$mice have recently been shown to develop severe craniofacial and axial skeleton defects (Dao et al. 2010), again highlighting the important pro-osteogenic functions of the Wnt $/ \beta$-catenin signaling pathway in skeletal development.

Gsk3 $\beta$ is another important intracellular negative regulator of the pathway. Although Gsk $3 \beta^{-/-}$mice die around embryonic days 13.5-14.5 (E13.5-E14.5), Gsk3 $\beta^{+/-}$mice survive and show increased bone formation (Kugimiya et al. 2007). Similarly, lithium chloride $(\mathrm{LiCl})$, a Gsk3 $\beta$ inhibitor, increased bone mass and osteoblast function in mice and rescued the low bone mass phenotype of the Lrp5 $5^{-/-}$mice (Clement-Lacroix et al. 2005). Consistent with this, $\mathrm{LiCl}$ treatment in humans is associated with a decreased incident of fractures (Vestergaard et al. 2005; Wilting et al. 2007). All of these results indicate that $\mathrm{Wnt} / \beta$-catenin signaling in osteoblasts regulates both bone formation and resorption.

Despite the important roles of Wnt $/ \beta$-catenin signaling in osteoblasts, one should not forget that it also acts directly in osteoclasts (Modarresi et al. 2009; Wei et al. 2011). Wnt/ $\beta$-catenin signaling blocks osteoclast differentiation by inhibiting RANKL signaling. Osteoclast differentiation is enhanced in $\beta$-catenin heterozygous mice, whereas stabilizing $\beta$-catenin in osteoclast precursors inhibits osteoclast differentiation.

Although the functional importance of Lrp5 in regulating bone mass is clear, the precise mechanism has become controversial. Studies in mouse models confirmed the human find- ings: Mice globally deficient for Lrp5 have decreased bone mass, whereas mice carrying the gain-of-function (GOF) Lrp5-G171V point mutations under the control of an osteoblast promoter displayed increased bone mass (Kato et al. 2002; Babij et al. 2003; Cui et al. 2011). The controversy originates from the model in which Lrp5 functions within the enterochromaffin cells of the small intestine to regulate the production of serotonin (Yadav et al. 2008). Increased serotonin secretion is associated with loss of Lrp5 and reduction in osteoblast activity, leading to lower bone mass. In support of this model, Yadav et al. (2008) found that conditional deletion of Lrp5 in the intestine led to low bone mass, whereas conditional deletion within the osteoblast had no discernible phenotype. Furthermore, intestinal-specific expression of the gain-of-function Lrp5-G171V allele led to increased bone mass, but osteoblast-specific expression of the same allele had no effect (Yadav et al. 2008). However, this model has recently been challenged when the characterization of independently derived mouse models carrying similar alterations in the Lrp5 locus suggested that Lrp5 did, as has been expected, function within the osteoblast and not in the intestine to control bone mass (Cui et al. 2011). In addition, recent work has shown that Lrp5 acts redundantly with Lrp6 within the osteochondral progenitor cells to mediate commitment to the osteoblast lineage (Joeng et al. 2011). The reasons for these different observations regarding Lrp5 function are currently unclear and will undoubtedly be the subject of additional investigation.

\section{WNT/ $\beta$-CATENIN SIGNALING IN OSTEOCYTES}

Osteocytes represent $>90 \%-95 \%$ of all bone cells and communicate through extensive dendritic processes present in canaliculi with one another, with cells on the bone surface, and in the bone marrow (Fig. 2). Osteocytes can recruit osteoclast precursors to stimulate bone resorption and regulate osteoblastic differentiation from a mesenchymal stem cell (Kamioka et al. 2001; Zhao et al. 2002; Heino et al. 2004). 
Similar to mice with deletions of $\beta$-catenin in osteoblasts, mice with deletion of $\beta$-catenin induced by the DMP1-cre (which is highly enriched in osteocytes) showed a severe low bone mass phenotype, which was associated with increased osteoclast activity caused by decreased Opg expression in osteocytes (Kramer et al. 2010).

Mechanical stress leads to the movement of bone fluid through the lacuno-canalicular system, generating shear stress that the osteocyte senses. Osteocytes were first proposed to be mechanosensory cells 20 years ago, when an increased ${ }^{3} \mathrm{H}$-uridine level was detected in osteocytes following mechanical loading in vivo (Pead et al. 1988). More recently, it has been shown that, in mice, ablation of osteocytes caused resistance to unloading-induced bone loss, providing the first direct evidence for the role of osteocytes in mechanotransduction (Tatsumi et al. 2007). Several reports have shown that $\beta$-catenin signaling is activated as a normal physiological response to mechanical loading in bone (Robinson et al. 2006). In the $\operatorname{Lrp} 5^{-/-}$ mice, the osteogenic response to mechanical loading of the ulna was dramatically reduced, with normal recruitment and activation of osteoblasts at the mechanically strained surface (Sawakami et al. 2006). This suggests that Lrp5 $5^{-/-}$ osteocytes may have a normal primary response to mechanic loading, whereas the intrinsic osteogenic abilities of osteoblasts and/or osteocytes are reduced in the absence of Lrp5. Thus, the osteoporotic phenotype of the Lrp5 $5^{-/-}$mouse could be due to inadequate processing of signals derived from mechanical stimulation. Consistent with this model, mice expressing the Lrp5 G171V mutation specifically in bone showed a higher sensitivity to mechanical loading with stronger $\beta$-catenin activation, and experienced significantly less bone loss induced by unloading (Akhter et al. 2004; Robinson et al. 2006; Saxon et al. 2011).

Osteocytes may be involved in a feedback signaling system to maintain bone-lining cells in a quiescent state under conditions of low mechanical load (Marotti et al. 1992; Martin 2000; Metz et al. 2003). A candidate to mediate such a feedback mechanism is Sost, which is
Wnt Signaling in Bone Development and Disease

specifically expressed in mature osteocytes and plays a negative regulatory role in bone formation (van Bezooijen et al. 2004; Poole et al. 2005). Sost has been reported to function as both an inhibitor of BMP signaling and as an inhibitor of Wnt $/ \beta$-catenin signaling by binding directly to LRP5 and LRP6 (Li et al. 2005; Semenov et al. 2005). Ulnar loading decreased Sost expression and increased bone formation rate in a strain dose-dependent manner (Robling et al. 2008). Sost ${ }^{-1-}$ mice were resistant to mechanical unloading-induced bone loss and failed to show decreased Wnt $/ \beta$-catenin signaling during unloading (Lin et al. 2009). Thus, Sost may represent an important primary response to mechanical loading. Mechanical loading may regulate bone mass by modulating the expression levels of this Wnt inhibitor.

In vitro models to mimic physiologic shear stress include steady fluid flow, pulsatile fluid flow, or oscillatory flow to generate shear stress on osteoblasts or osteoblast-like cells (Reich et al. 1990; Williams et al. 1994; Hillsley and Frangos 1997; Jacobs et al. 1998). There are limitations for these kinds of in vitro fluid flow shear stress on osteoblast cultures (Bonewald 2011), but they provide valuable information toward understanding the in vivo response to such forces. Consistent with the in vivo findings, in vitro studies also show that $\beta$-catenin signaling is required for the response to fluid shear stress (Lau et al. 2006; Robinson et al. 2006; Sawakami et al. 2006). In addition, some in vitro studies suggest that osteocytes support osteoclast formation through a response to fluid shear stress (Kim et al. 2006; You et al. 2008).

\section{WNT/ $\beta$-CATENIN SIGNALING IN BONE FRACTURE HEALING}

We briefly cover the function of Wnt $/ \beta$-catenin signaling in bone fracture healing here because this topic is covered in more detail in Whyte et al. (2012). Adult bone has the ability to regenerate after injury or fracture. In most aspects, fracture healing recapitulates key steps of embryonic bone development (Bruder et al. 1994); however, there are also differences between fracture healing and embryonic bone development. 
J.B. Regard et al.

For example, embryonic bone development does not go through an inflammatory response. Fracture healing involves the participation of hematopoietic cells, immune cells, and mesenchymal stem cells that are recruited from the surrounding tissues and the circulation. In classical histological terms, fracture healing can be divided into direct and indirect healing (Dimitriou et al. 2005). The majority of fracture healing is through an indirect healing process, which consists of three main phases: (1) the inflammatory stage, (2) the repair stage, and (3) the remodeling stage (Chen and Alman 2009). A microarray study specifies the process further into five specific physiological events: inflammation, intramembranous ossification, chondrogenesis, endochondral ossification, and remodeling (Hadjiargyrou et al. 2002).

Wnt signaling may be involved throughout the healing process by regulating a wide variety of cell-fate decisions associated with osteogenesis. Notably, the $\beta$-catenin signaling pathway is significantly activated in the fracture callus (Hadjiargyrou et al. 2002; Chen et al. 2007). Consistent with this, studies on the Topgal mouse, an in vivo LacZ reporter for $\mathrm{Wnt} / \beta$-catenin signaling, showed that LacZ activity was activated specifically at the site of injury (Kim et al. 2007).

Because mouse models with gain of function in Wnt signaling show high bone mass phenotypes, it is not surprising to find that the mice with an activated form of $\beta$-catenin in osteoblasts and the Axin $2^{-/}$mouse show dramatically enhanced bone healing (Chen et al. 2007; Minear et al. 2010). However, in a fracture-healing model involving both endochondral and intramembranous ossification, Wnt/ $\beta$-catenin signaling plays varying roles in different phases of fracture repair. For example, either increases or decreases in Wnt/ $\beta$-catenin signaling during early stages of healing inhibit the differentiation of mesenchymal stem cells into osteoblasts. At later stages, Wnt $/ \beta$-catenin signaling positively regulates osteoblasts after the undifferentiated cells have committed to the osteoblast lineage (Chen et al. 2007). Both recombinant Wnt3a and $\mathrm{LiCl}$ can enhance healing when the treatment starts after the fracture
(Chen et al. 2007; Minear et al. 2010). Similarly, an anti-Sost antibody can enhance bone healing in rats (Agholme et al. 2010). Conversely, Wnt inhibition in the injury site by adenoviral expression of DKK1 can prevent the differentiation of osteoblastic cells (Kim et al. 2007).

Although it is clear that Wnt $/ \beta$-catenin signaling plays a crucial role during fracture healing, this does not rule out the possibility that $\beta$-catenin-independent pathways are also involved. It has been reported that Wnts that often do not signal via the $\beta$-catenin pathway are upregulated during fracture healing (for review, see Chen and Alman 2009). In addition, periodontal ligament stem cells, a recently identified population of mesenchymal stem cells with bone-regeneration ability, were reported to have a lower osteogenic differentiation in inflammatory microenvironments, which might be due to inhibition of non-canonical Wnt pathways (Liu et al. 2011).

\section{WNT IN BONE CANCER AND METASTASIS}

The function of Wnt $/ \beta$-catenin signaling within the skeletal microenvironment has drawn the attention of not only academic, but also industry scientists and clinicians targeting this pathway to treat skeletal tumors. DKK1 has been proposed to be an important regulator in prostate cancer bone metastasis because alterations in DKK1 expression are linked to several tumor types with a propensity to grow in bone including prostate carcinoma, breast carcinoma, and multiple myeloma (Forget et al. 2007). Prostate cancer cells overexpressing DKK1 have a higher potential to metastasize into bone and generate osteolytic lesions (Thudi et al. 2010). DKK1 upregulation is a frequent event in mammary cancer, and increased serum levels of DKK1 are associated with the presence of bone metastasis in patients (Voorzanger-Rousselot et al. 2007; Bu et al. 2008). In multiple myeloma, the serum level of DKK1 is positively correlated with the presence of bone lesions, and anti-DKK1 antibody may be an effective adjunct in the treatment of multiple myeloma-associated bone disease (Tian et al. 2003; Yaccoby et al. 2007; Fulciniti et al. 2009; Heath et al. 2009). Based 
on these observations, several pharmaceutical companies have agents at various stages of clinical trials that target this pathway for treatment of bone metastases. For example, antibodies or small molecules that target DKK1 or SOST are in various stages of development for treating multiple myeloma and skeletal metastases (Rey and Ellies 2010).

\section{CONCLUDING REMARKS}

In this article, we attempt to summarize the current understanding of $\mathrm{Wnt} / \beta$-catenin signaling in skeletal tissues. Work from many groups in the past decade has clearly shown the importance of the Wnt/ $\beta$-catenin pathway in both embryonic and postnatal bone formation and homeostasis. Modulating this pathway is widely recognized as an important area of therapeutic development for osteoporosis, fracture healing, and tissue engineering. Moving forward, important questions still remain regarding the precise mechanism(s) by which Wnt/ $\beta$-catenin signaling regulates skeletal tissues and how this pathway interacts with other major pathways (e.g., BMP, Hedgehog, FGF, etc.) in the skeleton.

\section{ACKNOWLEDGMENTS}

We thank Darryl Leja and Julia Fekecs for preparing the figures. This work is supported by the Division of Intramural Research of the $\mathrm{Na}$ tional Institutes of Health, DHHS, to J.B.R. and Y.Y. and NIH R01AR053293 to B.O.W. and Z.Z.

\section{REFERENCES}

* Reference is also in this collection.

Agholme F, Li X, Isaksson H, Ke HZ, Aspenberg P. 2010. Sclerostin antibody treatment enhances metaphyseal bone healing in rats. J Bone Miner Res 25: 2412-2418.

Akhter MP, Wells DJ, Short SJ, Cullen DM, Johnson ML, Haynatzki GR, Babij P, Allen KM, Yaworsky PJ, Bex F, et al. 2004. Bone biomechanical properties in LRP5 mutant mice. Bone 35: 162-169.

Akiyama H, Lyons JP, Mori-Akiyama Y, Yang X, Zhang R, Zhang Z, Deng JM, Taketo MM, Nakamura T, Behringer $\mathrm{RR}$, et al. 2004. Interactions between Sox9 and $\beta$-catenin control chondrocyte differentiation. Genes Dev 18: 1072-1087.
Albers J, Schulze J, Beil FT, Gebauer M, Baranowsky A, Keller J, Marshall RP, Wintges K, Friedrich FW, Priemel M, et al. 2011. Control of bone formation by the serpentine receptor Frizzled-9. J Cell Biol 192: 1057-1072.

Babij P, Zhao W, Small C, Kharode Y, Yaworsky PJ, Bouxsein ML, Reddy PS, Bodine PV, Robinson JA, Bhat B, et al. 2003. High bone mass in mice expressing a mutant LRP5 gene. J Bone Miner Res 18: 960-974.

Balemans W, Ebeling M, Patel N, Van Hul E, Olson P, Dioszegi M, Lacza C, Wuyts W, Van Den Ende J, Willems P, et al. 2001. Increased bone density in sclerosteosis is due to the deficiency of a novel secreted protein (SOST). Hum Mol Genet 10: 537-543.

Balemans W, Patel N, Ebeling M, Van Hul E, Wuyts W, Lacza C, Dioszegi M, Dikkers FG, Hildering P, Willems PJ, et al. 2002. Identification of a $52 \mathrm{~kb}$ deletion downstream of the SOSTgene in patients with van Buchem disease. J Med Genet 39: 91-97.

Bennett CN, Longo KA, Wright WS, Suva LJ, Lane TF, Hankenson KD, MacDougald OA. 2005. Regulation of osteoblastogenesis and bone mass by Wnt10b. Proc Natl Acad Sci 102: 3324-3329.

Bodine PV, Zhao W, Kharode YP, Bex FJ, Lambert AJ, Goad MB, Gaur T, Stein GS, Lian JB, Komm BS. 2004. The Wnt antagonist secreted Frizzled-related protein-1 is a negative regulator of trabecular bone formation in adult mice. Mol Endocrinol 18: 1222-1237.

Boland GM, Perkins G, Hall DJ, Tuan RS. 2004. Wnt 3a promotes proliferation and suppresses osteogenic differentiation of adult human mesenchymal stem cells. J Cell Biochem 93: 1210-1230.

Bonewald LF. 2011. The amazing osteocyte. J Bone Miner Res 26: $229-238$.

Boyden LM, Mao J, Belsky J, Mitzner L, Farhi A, Mitnick MA, Wu D, Insogna K, Lifton RP. 2002. High bone density due to a mutation in LDL-receptor-related protein 5. N Engl J Med 346: 1513-1521.

Bruder SP, Fink DJ, Caplan AI. 1994. Mesenchymal stem cells in bone development, bone repair, and skeletal regeneration therapy. J Cell Biochem 56: 283-294.

Brunkow ME, Gardner JC, Van Ness J, Paeper BW, Kovacevich BR, Proll S, Skonier JE, Zhao L, Sabo PJ, Fu Y, et al. 2001. Bone dysplasia sclerosteosis results from loss of the SOST gene product, a novel cystine knot-containing protein. Am J Hum Genet 68: 577-589.

Bu G, Lu W, Liu CC, Selander K, Yoneda T, Hall C, Keller ET, Li Y. 2008. Breast cancer-derived Dickkopf1 inhibits osteoblast differentiation and osteoprotegerin expression: Implication for breast cancer osteolytic bone metastases. Int J Cancer 123: 1034-1042.

Carter M, Chen X, Slowinska B, Minnerath S, Glickstein S, Shi L, Campagne F, Weinstein H, Ross ME. 2005. Crooked tail (Cd) model of human folate-responsive neural tube defects is mutated in Wnt coreceptor lipoprotein receptor-related protein 6. Proc Natl Acad Sci 102: 1284312848 .

Chen Y, Alman BA. 2009. Wnt pathway, an essential role in bone regeneration. J Cell Biochem 106: 353-362.

Chen Y, Whetstone HC, Lin AC, Nadesan P, Wei Q, Poon R, Alman BA. 2007. $\beta$-Catenin signaling plays a disparate role in different phases of fracture repair: Implications for therapy to improve bone healing. PLoS Med 4: e249. 
J.B. Regard et al.

Cho HH, Kim YJ, Kim SJ, Kim JH, Bae YC, Ba B, Jung JS. 2006. Endogenous Wnt signaling promotes proliferation and suppresses osteogenic differentiation in human adipose derived stromal cells. Tissue Eng 12: 111-121.

Clement-Lacroix P, Ai M, Morvan F, Roman-Roman S, Vayssiere B, Belleville C, Estrera K, Warman ML, Baron R, Rawadi G. 2005. Lrp5-independent activation of Wnt signaling by lithium chloride increases bone formation and bone mass in mice. Proc Natl Acad Sci 102: 17406 17411.

Cui Y, Niziolek PJ, MacDonald BT, Zylstra CR, Alenina N, Robinson DR, Zhong Z, Matthes S, Jacobsen CM, Conlon RA, et al. 2011. Lrp5 functions in bone to regulate bone mass. Nat Med 17: 684-691.

Dao DY, Yang X, Flick LM, Chen D, Hilton MJ, O'Keefe RJ. 2010. Axin2 regulates chondrocyte maturation and axial skeletal development. J Orthop Res 28: 89-95.

Day TF, Guo X, Garrett-Beal L, Yang Y. 2005. Wnt/ $\beta$-catenin signaling in mesenchymal progenitors controls osteoblast and chondrocyte differentiation during vertebrate skeletogenesis. Dev Cell 8: 739-750.

de Boer J, Siddappa R, Gaspar C, van Apeldoorn A, Fodde R, van Blitterswijk C. 2004. Wnt signaling inhibits osteogenic differentiation of human mesenchymal stem cells. Bone 34: 818-826.

Dimitriou R, Tsiridis E, Giannoudis PV. 2005. Current concepts of molecular aspects of bone healing. Injury 36: 1392-1404.

Duncan EL, Danoy P, Kemp JP, Leo PJ, McCloskey E, Nicholson GC, Eastell R, Prince RL, Eisman JA, Jones G, et al. 2011. Genome-wide association study using extreme truncate selection identifies novel genes affecting bone mineral density and fracture risk. PLoS Genet 7: e1001372.

Eijken M, Meijer IM, Westbroek I, Koedam M, Chiba H, Uitterlinden AG, Pols HA, van Leeuwen JP. 2008. Wnt signaling acts and is regulated in a human osteoblast differentiation dependent manner. J Cell Biochem 104: $568-579$.

Ellwanger K, Saito H, Clement-Lacroix P, Maltry N, Niedermeyer J, Lee WK, Baron R, Rawadi G, Westphal H, Niehrs C. 2008. Targeted disruption of the Wnt regulator Kremen induces limb defects and high bone density. Mol Cell Biol 28: 4875-4882.

Forget MA, Turcotte S, Beauseigle D, Godin-Ethier J, Pelletier S, Martin J, Tanguay S, Lapointe R. 2007. The Wnt pathway regulator DKK1 is preferentially expressed in hormone-resistant breast tumours and in some common cancer types. Br J Cancer 96: 646-653.

Fu J, Ivy Yu HM, Maruyama T, Mirando AJ, Hsu W. 2011. Gpr177/mouse Wntless is essential for Wnt-mediated craniofacial and brain development. Dev Dyn 240: 365-371.

Fujino T, Asaba H, Kang MJ, Ikeda Y, Sone H, Takada S, Kim DH, Ioka RX, Ono M, Tomoyori H, et al. 2003. Lowdensity lipoprotein receptor-related protein 5 (LRP5) is essential for normal cholesterol metabolism and glucoseinduced insulin secretion. Proc Natl Acad Sci 100: 229234.

Fulciniti M, Tassone P, Hideshima T, Vallet S, Nanjappa $\mathrm{P}$, Ettenberg SA, Shen Z, Patel N, Tai YT, Chauhan D, et al.
2009. Anti-DKK1 mAb (BHQ880) as a potential therapeutic agent for multiple myeloma. Blood 114: 371-379.

Gardner JC, van Bezooijen RL, Mervis B, Hamdy NA, Lowik CW, Hamersma H, Beighton P, Papapoulos SE. 2005. Bone mineral density in sclerosteosis; affected individuals and gene carriers. J Clin Endocrinol Metab 90: 63926395.

Gaur T, Rich L, Lengner CJ, Hussain S, Trevant B, Ayers D, Stein JL, Bodine PV, Komm BS, Stein GS, et al. 2006. Secreted Frizzled related protein 1 regulates Wnt signaling for BMP2 induced chondrocyte differentiation. J Cell Physiol 208: 87-96.

Glass DA II, Bialek P, Ahn JD, Starbuck M, Patel MS, Clevers H, Taketo MM, Long F, McMahon AP, Lang RA, et al. 2005. Canonical Wnt signaling in differentiated osteoblasts controls osteoclast differentiation. Dev Cell 8: 751-764.

Gong Y, Slee RB, Fukai N, Rawadi G, Roman-Roman S, Reginato AM, Wang H, Cundy T, Glorieux FH, Lev D, et al. 2001. LDL receptor-related protein 5 (LRP5) affects bone accrual and eye development. Cell 107: 513-523.

Guo X, Day TF, Jiang X, Garrett-Beal L, Topol L, Yang Y. 2004 . Wnt/ $\beta$-catenin signaling is sufficient and necessary for synovial joint formation. Genes Dev 18: $2404-$ 2417.

Guo J, Liu M, Yang D, Bouxsein ML, Saito H, Galvin RJ, Kuhstoss SA, Thomas CC, Schipani E, Baron R, et al. 2010. Suppression of Wnt signaling by Dkk1 attenuates PTH-mediated stromal cell response and new bone formation. Cell Metab 11: 161-171.

Hadjiargyrou M, Lombardo F, Zhao S, Ahrens W, Joo J, Ahn H, Jurman M, White DW, Rubin CT. 2002. Transcriptional profiling of bone regeneration. Insight into the molecular complexity of wound repair. J Biol Chem 277: 30177-30182.

Hausmann G, Banziger C, Basler K. 2007. Helping Wingless take flight: How WNT proteins are secreted. Nat Rev Mol Cell Biol 8: 331-336.

Heath DJ, Chantry AD, Buckle CH, Coulton L, Shaughnessy JD Jr, Evans HR, Snowden JA, Stover DR, Vanderkerken K, Croucher PI. 2009. Inhibiting Dickkopf-1 (Dkk1) removes suppression of bone formation and prevents the development of osteolytic bone disease in multiple myeloma. J Bone Miner Res 24: 425-436.

Heino TJ, Hentunen TA, Vaananen HK. 2004. Conditioned medium from osteocytes stimulates the proliferation of bone marrow mesenchymal stem cells and their differentiation into osteoblasts. Exp Cell Res 294: 458-468.

Hill TP, Spater D, Taketo MM, Birchmeier W, Hartmann C. 2005. Canonical Wnt $/ \beta$-catenin signaling prevents osteoblasts from differentiating into chondrocytes. Dev Cell 8: $727-738$.

Hillsley MV, Frangos JA. 1997. Alkaline phosphatase in osteoblasts is down-regulated by pulsatile fluid flow. Calcif Tissue Int 60: 48-53.

Holmen SL, Giambernardi TA, Zylstra CR, Buckner-Berghuis BD, Resau JH, Hess JF, Glatt V, Bouxsein ML, Ai M, Warman ML, et al. 2004. Decreased BMD and limb deformities in mice carrying mutations in both Lrp5 and Lrp6. J Bone Miner Res 19: 2033-2040.

Holmen SL, Zylstra CR, Mukherjee A, Sigler RE, Faugere MC, Bouxsein ML, Deng L, Clemens TL, Williams BO. 
2005. Essential role of $\beta$-catenin in postnatal bone acquisition. J Biol Chem 280: 21162-21168.

Hu H, Hilton MJ, Tu X, Yu K, Ornitz DM, Long F. 2005. Sequential roles of Hedgehog and Wnt signaling in osteoblast development. Development 132: 49-60.

Jacobs CR, Yellowley CE, Davis BR, Zhou Z, Cimbala JM, Donahue HJ. 1998. Differential effect of steady versus oscillating flow on bone cells. J Biomech 31: 969-976.

Joeng KS, Schumacher CA, Zylstra-Diegel CR, Long F, Williams BO. 2011. Lrp5 and Lrp6 redundantly control skeletal development in the mouse embryo. Dev Biol 359: 222-229.

Kahler RA, Westendorf JJ. 2003. Lymphoid enhancer factor1 and $\beta$-catenin inhibit Runx2-dependent transcriptional activation of the osteocalcin promoter. J Biol Chem 278: 11937-11944.

Kahler RA, Galindo M, Lian J, Stein GS, van Wijnen AJ, Westendorf JJ. 2006. Lymphocyte enhancer-binding factor 1 (Lef1) inhibits terminal differentiation of osteoblasts. J Cell Biochem 97: 969-983.

Kahler RA, Yingst SM, Hoeppner LH, Jensen ED, Krawczak D, Oxford JT, Westendorf JJ. 2008. Collagen 11a1 is indirectly activated by lymphocyte enhancer-binding factor 1 (Lef1) and negatively regulates osteoblast maturation. Matrix Biol 27: 330-338.

Kamioka H, Honjo T, Takano-Yamamoto T. 2001. A threedimensional distribution of osteocyte processes revealed by the combination of confocal laser scanning microscopy and differential interference contrast microscopy. Bone 28: 145-149.

Kato M, Patel MS, Levasseur R, Lobov I, Chang BH, Glass DA II, Hartmann C, Li L, Hwang TH, Brayton CF, et al. 2002. Cbfa1-independent decrease in osteoblast proliferation, osteopenia, and persistent embryonic eye vascularization in mice deficient in Lrp5, a Wnt coreceptor. J Cell Biol 157: 303-314.

Kim CH, You L, Yellowley CE, Jacobs CR. 2006. Oscillatory fluid flow-induced shear stress decreases osteoclastogenesis through RANKL and OPG signaling. Bone 39: 10431047.

Kim JB, Leucht P, Lam K, Luppen C, Ten Berge D, Nusse R, Helms JA. 2007. Bone regeneration is regulated by wnt signaling. J Bone Miner Res 22: 1913-1923.

Kokubu C, Heinzmann U, Kokubu T, Sakai N, Kubota T, Kawai M, Wahl MB, Galceran J, Grosschedl R, Ozono K, et al. 2004. Skeletal defects in ringelschwanzmutant mice reveal that Lrp6 is required for proper somitogenesis and osteogenesis. Development 131: 5469-5480.

Koyama E, Shibukawa Y, Nagayama M, Sugito H, Young B, Yuasa T, Okabe T, Ochiai T, Kamiya N, Rountree RB, et al. 2008. A distinct cohort of progenitor cells participates in synovial joint and articular cartilage formation during mouse limb skeletogenesis. Dev Biol 316: 62-73.

Kramer I, Halleux C, Keller H, Pegurri M, Gooi JH, Weber PB, Feng JQ, Bonewald LF, Kneissel M. 2010. Osteocyte $\mathrm{Wnt} / \beta$-catenin signaling is required for normal bone homeostasis. Mol Cell Biol 30: 3071-3085.

Kugimiya F, Kawaguchi H, Ohba S, Kawamura N, Hirata M, Chikuda H, Azuma Y, Woodgett JR, Nakamura K, Chung UI. 2007. GSK-3 $\beta$ controls osteogenesis through regulating Runx2 activity. PLoS ONE 2: e837.
Lammi L, Arte S, Somer M, Jarvinen H, Lahermo P, Thesleff I, Pirinen S, Nieminen P. 2004. Mutations in AXIN2 cause familial tooth agenesis and predispose to colorectal cancer. Am J Hum Genet 74: 1043-1050.

Lau KH, Kapur S, Kesavan C, Baylink DJ. 2006. Up-regulation of the Wnt, estrogen receptor, insulin-like growth factor-I, and bone morphogenetic protein pathways in $\mathrm{C} 57 \mathrm{BL} / 6 \mathrm{~J}$ osteoblasts as opposed to $\mathrm{C} 3 \mathrm{H} / \mathrm{HeJ}$ osteoblasts in part contributes to the differential anabolic response to fluid shear. J Biol Chem 281: 9576-9588.

Li X, Zhang Y, Kang H, Liu W, Liu P, Zhang J, Harris SE, Wu D. 2005. Sclerostin binds to LRP5/6 and antagonizes canonical Wnt signaling. J Biol Chem 280: 19883-19887.

Li J, Sarosi I, Cattley RC, Pretorius J, Asuncion F, Grisanti M, Morony S, Adamu S, Geng Z, Qiu W, et al. 2006. Dkk1mediated inhibition of Wnt signaling in bone results in osteopenia. Bone 39: 754-766.

Li X, Ominsky MS, Niu QT, Sun N, Daugherty B, D'Agostin D, Kurahara C, Gao Y, Cao J, Gong J, et al. 2008. Targeted deletion of the sclerostingene in mice results in increased bone formation and bone strength. J Bone Miner Res 23: $860-869$.

Li X, Ominsky MS, Warmington KS, Morony S, Gong J, Cao J, Gao Y, Shalhoub V, Tipton B, Haldankar R, et al. 2009. Sclerostin antibody treatment increases bone formation, bone mass, and bone strength in a rat model of postmenopausal osteoporosis. J Bone Miner Res 24: 578-588.

Lin C, Jiang X, Dai Z, Guo X, Weng T, Wang J, Li Y, Feng G, Gao X, He L. 2009. Sclerostin mediates bone response to mechanical unloading through antagonizing $\mathrm{Wnt} / \beta$ catenin signaling. J Bone Miner Res 24: 1651-1661.

Little RD, Carulli JP, Del Mastro RG, Dupuis J, Osborne M, Folz C, Manning SP, Swain PM, Zhao SC, Eustace B, et al. 2002. A mutation in the LDL receptor-related protein 5 gene results in the autosomal dominant high-bone-mass trait. Am J Hum Genet 70: 11-19.

Liu B, Yu HM, Hsu W. 2007. Craniosynostosis caused by Axin2 deficiency is mediated through distinct functions of $\beta$-catenin in proliferation and differentiation. Dev Biol 301: 298-308.

Liu N, Shi S, Deng M, Tang L, Zhang G, Liu N, Ding B, Liu W, Liu Y, Shi H, et al. 2011. High levels of $\beta$-catenin signaling reduce osteogenic differentiation of stem cells in inflammatory microenvironments through inhibition of the noncanonical Wnt pathway. J Bone Miner Res 26: 2082-2095.

Lorenowicz MJ, Korswagen HC. 2009. Sailing with the Wnt: Charting the Wnt processing and secretion route. Exp Cell Res 315: 2683-2689.

Lories RJ, Peeters J, Bakker A, Tylzanowski P, Derese I, Schrooten J, Thomas JT, Luyten FP. 2007. Articular cartilage and biomechanical properties of the long bones in Frzb-knockout mice. Arthritis Rheum 56: 4095-4103.

Loughlin J, Dowling B, Chapman K, Marcelline L, Mustafa Z, Southam L, Ferreira A, Ciesielski C, Carson DA, Corr M. 2004. Functional variants within the secreted Frizzled-related protein 3 gene are associated with hip osteoarthritis in females. Proc Natl Acad Sci 101: 9757-9762.

MacDonald BT, Joiner DM, Oyserman SM, Sharma P, Goldstein SA, He X, Hauschka PV. 2007. Bone mass is inversely proportional to Dkk1 levels in mice. Bone 41:331-339. 
J.B. Regard et al.

Mak KK, Chen MH, Day TF, Chuang PT, Yang Y. 2006. Wnt/ $\beta$-catenin signaling interacts differentially with Ihh signaling in controlling endochondral bone and synovial joint formation. Development 133: 3695-3707.

Mani A, Radhakrishnan J, Wang H, Mani MA, Nelson-Williams C, Carew KS, Mane S, Najmabadi H, Wu D, Lifton RP. 2007. LRP6 mutation in a family with early coronary disease and metabolic risk factors. Science 315: 1278 1282.

Marotti G, Ferretti M, Muglia MA, Palumbo C, Palazzini S. 1992. A quantitative evaluation of osteoblast-osteocyte relationships on growing endosteal surface of rabbit tibiae. Bone 13: 363-368.

Martin RB. 2000. Does osteocyte formation cause the nonlinear refilling of osteons? Bone 26: 71-78.

Metz LN, Martin RB, Turner AS. 2003. Histomorphometric analysis of the effects of osteocyte density on osteonal morphology and remodeling. Bone 33: 753-759.

Minear S, Leucht P, Jiang J, Liu B, Zeng A, Fuerer C, Nusse R, Helms Ja. 2010. Wnt proteins promote bone regeneration. Sci Transl Med 2: 29ra30.

Modarresi R, Xiang Z, Yin M, Laurence J. 2009. WNT/ $\beta$ catenin signaling is involved in regulation of osteoclast differentiation by human immunodeficiency virus protease inhibitor ritonavir: Relationship to human immunodeficiency virus-linked bone mineral loss. Am J Pathol 174:123-135.

Morvan F, Boulukos K, Clement-Lacroix P, Roman Roman S, Suc-Royer I, Vayssiere B, Ammann P, Martin P, Pinho S, Pognonec P, et al. 2006. Deletion of a single allele of the Dkk1 gene leads to an increase in bone formation and bone mass. J Bone Miner Res 21: 934-945.

Mukhopadhyay M, Shtrom S, Rodriguez-Esteban C, Chen L, Tsukui T, Gomer L, Dorward DW, Glinka A, Grinberg A, Huang SP, et al. 2001. Dickkopf1 is required for embryonic head induction and limb morphogenesis in the mouse. Dev Cell 1: 423-434.

Niemann S, Zhao C, Pascu F, Stahl U, Aulepp U, Niswander L, Weber JL, Muller U. 2004. Homozygous WNT3 mutation causes tetra-amelia in a large consanguineous family. Am J Hum Genet 74: 558-563.

Noh T, Gabet Y, Cogan J, Shi Y, Tank A, Sasaki T, Criswell B, Dixon A, Lee C, Tam J, et al. 2009. Lef1 haploinsufficient mice display a low turnover and low bone mass phenotype in a gender- and age-specific manner. PLoS ONE 4: e5438.

Pead MJ, Suswillo R, Skerry TM, Vedi S, Lanyon LE. 1988. Increased ${ }^{3} \mathrm{H}$-uridine levels in osteocytes following a single short period of dynamic bone loading in vivo. Calcif Tissue Int 43: 92-96.

Poole KE, van Bezooijen RL, Loveridge N, Hamersma H, Papapoulos SE, Lowik CW, Reeve J. 2005. Sclerostin is a delayed secreted product of osteocytes that inhibits bone formation. FASEB J 19: 1842-1844.

Regard JB, Cherman N, Palmer D, Kuznetsov SA, Celi FS, Guettier JM, Chen M, Bhattacharyya N, Wess J, Coughlin SR, et al. 2011. Wnt/ $\beta$-catenin signaling is differentially regulated by $\mathrm{G} \alpha$ proteins and contributes to fibrous dysplasia. Proc Natl Acad Sci 108: 20101-20106.

Reich KM, Gay CV, Frangos JA. 1990. Fluid shear stress as a mediator of osteoblast cyclic adenosine monophosphate production. J Cell Physiol 143: 100-104.
Reinhold MI, Kapadia RM, Liao Z, Naski MC. 2006. The Wnt-inducible transcription factor Twist 1 inhibits chondrogenesis. J Biol Chem 281: 1381-1388.

Rey JP, Ellies DL. 2010. Wnt modulators in the biotech pipeline. Dev Dyn 239: 102-114.

Robinson JA, Chatterjee-Kishore M, Yaworsky PJ, Cullen DM, Zhao W, Li C, Kharode Y, Sauter L, Babij P, Brown $\mathrm{EL}$, et al. 2006. Wnt $/ \beta$-catenin signaling is a normal physiological response to mechanical loading in bone. J Biol Chem 281: 31720-31728.

Robling AG, Niziolek PJ, Baldridge La, Condon KW, Allen MR, Alam I, Mantila SM, Gluhak-Heinrich J, Bellido TM, Harris SE, et al. 2008. Mechanical stimulation of bone in vivo reduces osteocyte expression of Sost/sclerostin. J Biol Chem 283: 5866-5875.

Rodda SJ, McMahon AP. 2006. Distinct roles for Hedgehog and canonical Wnt signaling in specification, differentiation and maintenance of osteoblast progenitors. Development 133: 3231-3244.

Rudnicki JA, Brown AM. 1997. Inhibition of chondrogenesis by Wnt gene expression in vivo and in vitro. Dev Biol 185: 104-118.

Saarinen A, Valimaki VV, Valimaki MJ, Loyttyniemi E, Auro K, Uusen P, Kuris M, Lehesjoki AE, Makitie O. 2007. The A1330V polymorphism of the low-density lipoprotein receptor-related protein 5 gene (LRP5) associates with low peak bone mass in young healthy men. Bone 40: 1006-1012.

Sawakami K, Robling AG, Ai M, Pitner ND, Liu D, Warden SJ, Li J, Maye P, Rowe DW, Duncan RL, et al. 2006. The Wnt co-receptor LRP5 is essential for skeletal mechanotransduction but not for the anabolic bone response to parathyroid hormone treatment. J Biol Chem 281: 23698-23711.

Saxon LK, Jackson BF, Sugiyama T, Lanyon LE, Price JS. 2011. Analysis of multiple bone responses to graded strains above functional levels, and to disuse, in mice in vivo show that the human Lrp5 G171V High Bone Mass mutation increases the osteogenic response to loading but that lack of Lrp5 activity reduces it. Bone 49:184-193.

Schulze J, Seitz S, Saito H, Schneebauer M, Marshall RP, Baranowsky A, Busse B, Schilling AF, Friedrich FW, Albers J, et al. 2010. Negative regulation of bone formation by the transmembrane Wnt antagonist Kremen-2. PLoS ONE 5: e10309.

Semenov M, Tamai K, He X. 2005. SOST is a ligand for LRP5/LRP6 and a Wnt signaling inhibitor. J Biol Chem 280: $26770-26775$.

Sims AM, Shephard N, Carter K, Doan T, Dowling A, Duncan EL, Eisman J, Jones G, Nicholson G, Prince R, et al. 2008. Genetic analyses in a sample of individuals with high or low BMD shows association with multiple Wnt pathway genes. J Bone Miner Res 23: 499-506.

Spater D, Hill TP, Gruber M, Hartmann C. 2006. Role of canonical Wnt-signalling in joint formation. Eur Cell Mater 12: 71-80.

Stefater JA III, Lewkowich I, Rao S, Mariggi G, Carpenter AC, Burr AR, Fan J, Ajima R, Molkentin JD, Williams BO, et al. 2011. Regulation of angiogenesis by a non-canonical Wnt-Flt1 pathway in myeloid cells. Nature 474: 511515. 
Tatsumi S, Ishii K, Amizuka N, Li M, Kobayashi T, Kohno K, Ito M, Takeshita S, Ikeda K. 2007. Targeted ablation of osteocytes induces osteoporosis with defective mechanotransduction. Cell Metab 5: 464-475.

Thudi NK, Martin CK, Murahari S, Shu ST, Lanigan LG, Werbeck JL, Keller ET, McCauley LK, Pinzone JJ, Rosol TJ. 2010. Dickkopf-1 (DKK-1) stimulated prostate cancer growth and metastasis and inhibited bone formation in osteoblastic bone metastases. Prostate 71: 615-625.

Tian E, Zhan F, Walker R, Rasmussen E, Ma Y, Barlogie B Shaughnessy JD Jr. 2003. The role of the Wnt-signaling antagonist DKK1 in the development of osteolytic lesions in multiple myeloma. N Engl J Med 349: 2483-2494.

Tu X, Joeng KS, Nakayama KI, Nakayama K, Rajagopal J, Carroll TJ, McMahon AP, Long F. 2007. Noncanonical Wnt signaling through G protein-linked PKC $\delta$ activation promotes bone formation. Dev Cell 12: 113-127.

Uitterlinden AG, Arp PP, Paeper BW, Charmley P, Proll S, Rivadeneira F, Fang Y, van Meurs JB, Britschgi TB, Latham JA, et al. 2004. Polymorphisms in the sclerosteosis/van Buchem disease gene (SOST) region are associated with bone-mineral density in elderly whites. $A m \mathrm{~J}$ Hum Genet 75: 1032-1045.

van Bezooijen RL, Roelen BA, Visser A, van der Wee-Pals L, de Wilt E, Karperien M, Hamersma H, Papapoulos SE, ten Dijke P, Lowik CW. 2004. Sclerostin is an osteocyteexpressed negative regulator of bone formation, but not a classical BMP antagonist. J Exp Med 199: 805-814.

van Meurs JB, Rivadeneira F, Jhamai M, Hugens W, Hofman A, van Leeuwen JP, Pols HA, Uitterlinden AG. 2006. Common genetic variation of the low-density lipoprotein receptor-related protein 5 and 6 genes determines fracture risk in elderly white men. J Bone Miner Res 21: 141-150.

Van Wesenbeeck L, Cleiren E, Gram J, Beals RK, Benichou O, Scopelliti D, Key L, Renton T, Bartels C, Gong Y, et al. 2003. Six novel missense mutations in the LDL receptorrelated protein 5 (LRP5) gene in different conditions with an increased bone density. Am J Hum Genet 72: 763-771.

Vestergaard P, Rejnmark L, Mosekilde L. 2005. Reduced relative risk of fractures among users of lithium. Calcif Tissue Int 77: 1-8.

Voorzanger-Rousselot N, Goehrig D, Journe F, Doriath V, Body JJ, Clezardin P, Garnero P. 2007. Increased Dickkopf-1 expression in breast cancer bone metastases. $\mathrm{Br} \mathrm{J}$ Cancer 97: 964-970.

Wei W, Zeve D, Suh JM, Wang X, Du Y, Zerwekh JE, Dechow PC, Graff JM, Wan Y. 2011. Biphasic and dosage-dependent regulation of osteoclastogenesis by $\beta$-catenin. $\mathrm{Mol}$ Cell Biol 31: 4706-4719.
* Whyte JL, Smith AA, Helms JA. 2012. Wnt signaling and injury repair. Cold Spring Harb Perspect Biol doi: 10.1101/cshperspect.a008078.

Williams JL, Iannotti JP, Ham A, Bleuit J, Chen JH. 1994. Effects of fluid shear stress on bone cells. Biorheology 31: $163-170$.

Wilting I, de Vries F, Thio BM, Cooper C, Heerdink ER, Leufkens HG, Nolen WA, Egberts AC, van Staa TP. 2007. Lithium use and the risk of fractures. Bone 40: 1252-1258.

Winkler DG, Sutherland MK, Geoghegan JC, Yu C, Hayes T, Skonier JE, Shpektor D, Jonas M, Kovacevich BR, Staehling-Hampton K, et al. 2003. Osteocyte control of bone formation via sclerostin, a novel BMP antagonist. $E M B O$ J 22: 6267-6276.

Yaccoby S, Ling W, Zhan F, Walker R, Barlogie B, Shaughnessy JD Jr. 2007. Antibody-based inhibition of DKK1 suppresses tumor-induced bone resorption and multiple myeloma growth in vivo. Blood 109: 2106-2111.

Yadav VK, Ryu JH, Suda N, Tanaka KF, Gingrich JA, Schutz G, Glorieux FH, Chiang CY, Zajac JD, Insogna KL, et al. 2008. Lrp5 controls bone formation by inhibiting serotonin synthesis in the duodenum. Cell 135: 825-837.

You L, Temiyasathit S, Lee P, Kim CH, Tummala P, Yao W, Kingery W, Malone AM, Kwon RY, Jacobs CR. 2008. Osteocytes as mechanosensors in the inhibition of bone resorption due to mechanical loading. Bone 42: 172-179.

Yu HM, Jerchow B, Sheu TJ, Liu B, Costantini F, Puzas JE, Birchmeier W, Hsu W. 2005. The role of Axin2 in calvarial morphogenesis and craniosynostosis. Development 132: 1995-2005.

Zhang S, Cagatay T, Amanai M, Zhang M, Kline J, Castrillon DH, Ashfaq R, Oz OK, Wharton KA Jr. 2007. Viable mice with compound mutations in the Wnt/Dvl pathway antagonists nkd1 and nkd2. Mol Cell Biol 27: 4454-4464.

Zhao S, Zhang YK, Harris S, Ahuja SS, Bonewald LF. 2002. MLO-Y4 osteocyte-like cells support osteoclast formation and activation. J Bone Miner Res 17: 2068-2079.

Zhu M, Tang D, Wu Q, Hao S, Chen M, Xie C, Rosier RN, O'Keefe RJ, Zuscik M, Chen D. 2009. Activation of $\beta$ catenin signaling in articular chondrocytes leads to osteoarthritis-like phenotype in adult $\beta$-catenin conditional activation mice. J Bone Miner Res 24: 12-21.

Zylstra CR, Wan C, VanKoevering KK, Sanders AK, Lindvall C, Clemens TL, Williams BO. 2008. Gene targeting approaches in mice: Assessing the roles of LRP5 and LRP6 in osteoblasts. J Musculoskelet Neuronal Interact 8: 291293. 


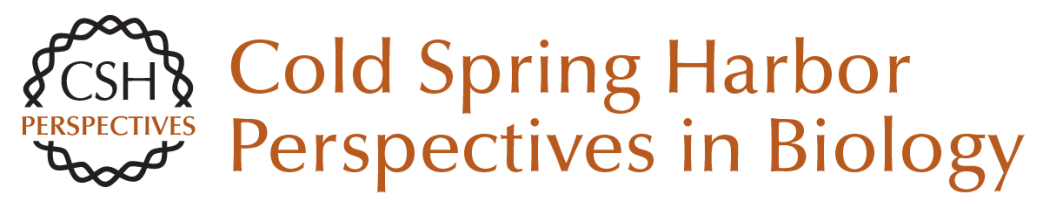

\title{
Wnt Signaling in Bone Development and Disease: Making Stronger Bone with Wnts
}

\author{
Jean B. Regard, Zhendong Zhong, Bart O. Williams and Yingzi Yang \\ Cold Spring Harb Perspect Biol 2012; doi: 10.1101/cshperspect.a007997
}

\section{Subject Collection Wnt Signaling}

Wnt Signaling in Vertebrate Axis Specification Hiroki Hikasa and Sergei Y. Sokol

Secreted and Transmembrane Wnt Inhibitors and Activators Cristina-Maria Cruciat and Christof Niehrs

Wnt Signaling in Normal and Malignant Hematopoiesis

William Lento, Kendra Congdon, Carlijn Voermans, et al.

Frizzled and LRP5/6 Receptors for Wnt/ $\beta$-Catenin Signaling

Bryan T. MacDonald and Xi He

TCF/LEFs and Wnt Signaling in the Nucleus

Ken M. Cadigan and Marian L. Waterman

\section{Alternative Wnt Pathways and Receptors Renée van Amerongen}

ß-Catenin-Dependent Wnt Signaling in C. elegans: Teaching an Old Dog a New Trick Belinda M. Jackson and David M. Eisenmann

The Evolution of the Wnt Pathway Thomas W. Holstein
The $\beta$-Catenin Destruction Complex Jennifer L. Stamos and William I. Weis

Wnt Signaling in Skin Development, Homeostasis, and Disease Xinhong Lim and Roel Nusse

Wnt Signaling in Bone Development and Disease:

Making Stronger Bone with Wnts Jean B. Regard, Zhendong Zhong, Bart O. Williams, et al.

Targeting Wnt Pathways in Disease Zachary F. Zimmerman, Randall T. Moon and Andy J. Chien

Wnt Signaling in Mammary Glands: Plastic Cell

Fates and Combinatorial Signaling Caroline M. Alexander, Shruti Goel, Saja A. Fakhraldeen, et al.

Wnt Signaling and Injury Repair Jemima L. Whyte, Andrew A. Smith and Jill A. Helms

Wnt Signaling and Forebrain Development Susan J. Harrison-Uy and Samuel J. Pleasure

Wnt Signaling in Neuromuscular Junction Development Kate Koles and Vivian Budnik

For additional articles in this collection, see http://cshperspectives.cshlp.org/cgi/collection/

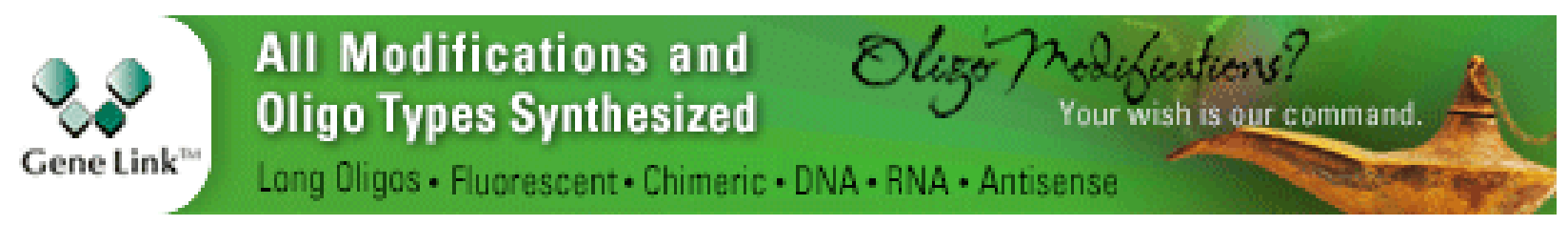

